\title{
Islamophobia and Arab and Muslim Women’s Activism
}

\author{
Tara Povey
}

\begin{abstract}
This paper will discuss the impact of Islamophobia and racism on Arab and Muslim women's activism. Arab and Muslim women living in diaspora in Muslim majority countries such as Iran face many difficulties as activists yet they have successfully challenged patriarchal readings of Islamic religious texts and fought for legislative and political change. In Western countries and Australia, Arab and Muslim women activists are playing a role in opposing poverty, war and neo-liberalism, in building communities and ensuring community survival. They have also struggled for a diasporic identity that reflects their diverse positions and resists notions of Australia as exclusively white and Christian. However Arab and Muslim women's activism in Australia in recent years has occurred in the context of the Australian government's attempt to shore up public support for the continuance of the 'War on Terror' through domestic policy and language which marginalises and de-humanises people of Islamic cultures. Therefore this paper argues that in Australia, Arab and Muslim women face significant obstacles to their activism. Foremost among these are the experience of racism and Islamophobia and the resurgence of the politics of assimilation in Australia.
\end{abstract}

\section{Introduction}

This paper will discuss the impact of Islamophobia on Arab and Muslim women's activism. Arab and Muslim women in Australia are from a wide variety of different backgrounds and their experience varies in terms of age, class, ethnicity, religious background and beliefs, profession, education and family relationships. They are active in a number of different ways, in anti-poverty programs, in anti-war and antiracist movements, union movements and in welfare and community organisations. In the second section, I will discuss my methodology and conceptual framework. A critical theme that runs through this paper is that contemporary debates around Arab and Muslim women are essentialising. By this I mean that debates which focus on abstract questions such as the symbolic meaning of the hijab assume that the experience of Arab and Muslim women is uniform and unchanging and has no relation to the material conditions of their lives. These perspectives therefore fail to consider the ways in which structures such as class, ethnicity, age and gender intersect in women's lives to create a complex lived experience, which, I argue, gives rise to their strategies of resistance. In this second section, I will also discuss theoretical approaches to diaspora, class, identity, racism, Islamophobia, gender and the politics 
of assimilation. I argue in order to capture the complexity and dynamism of women's activism a critical approach is needed which takes on essentialist and racist arguments about the role of Arab and Muslim women. In the third section, I will discuss the use of international comparative frameworks to examine the material conditions of women's lives in diaspora in Muslim majority countries and in Western countries, with reference to Afghan Women, (2007) by Elaheh Rostami-Povey. In the fourth section, I will present my empirical research, which is based on in-depth interviews with three activists in Sydney carried out in 2008. Using quotes from these interviews, I will demonstrate three points: Firstly that despite views of Arab and Muslim communities as 'insular' and conservative', Arab and Muslim activists have high levels of involvement in political movements and community welfare organisations. Secondly that they are articulating an Australian-diasporic identity that is based on their actual experience and challenges notions of 'white Australia' from which they are excluded. Thirdly, that their task is being made much harder by the level of racism and Islamophobia that is directed to them and by the resurgence of the politics of assimilation in Australia.

\section{Methodology and Conceptual Framework}

My research methodology is based on qualitative participatory research approaches which have the benefit of allowing the researcher to learn from the knowledge and experience of women and to use that experience as a means of empowerment (Cook and Kothari, 2001; Laws et al., 2003). A critical theme that runs through this paper is that contemporary debates about Arabs, Muslims and Islam fail to capture the dynamism, diversity and complexity of actual lived experience. Therefore, despite the criticisms of this approach as being too subjectivist, I believe that it is important to hear women speak in their own words (Rostami-Povey, 2007; Khalili, 2007). The aim was not to provide a representative sample of the views of all Australian women who identify as either Arab and/or Muslim but to learn from the participant's specialised knowledge, although each of the participants felt that their experience was shared in the wider community. Therefore the aim is to produce qualitative data that can be understood in the contemporary Australian political context and can be used for the purpose of theory development. 


\section{Diaspora, Groups and Identity}

This paper is about Arab and Muslim women's activism in Australia and so terms such as ‘diaspora’, 'identity’ and ‘community' are important yet problematic concepts. The term 'diaspora' is associated with the mass migration of a population who have suffered the traumatic experience of loss of homeland (Gilroy, 1993). In more recent literature the meaning of the term has broadened to encompass second, third and fourth generation descendents of migrants and those not associated with specific ethno-cultural groups. However, as its meaning has proliferated, it has become harder to define what constitutes 'diaspora' and arguably this has led to a loss in the conceptual coherence of the term (Brubaker, 2005). In this paper I use 'diaspora' as Brubaker suggests as a claim rather than an entity (2005, p.12). I also argue that the 'claim' diaspora is intimately connected to the lived experience of women and involves a complex process of positive political identification rather than the more negative 'boundary maintenance' strategies that Brubaker describes (2005, p. 6). It is important to recognise, as Edward Said argues, that 'identities' are not fixed, permanent and immutable (Said, 1996) but that in fact all identities are hybrid, involve processes of making claims and are "political interventions and constructions of social reality” (Anthias, 2001, p. 619). One of the problematic aspects of how antiracism has been conceptualised and written about in academic and policy making circles has been the reification of static concepts of 'ethnicity', 'community' and 'groupness' (Anthias and Yuval-Davis, 1992). However, Anthias (2001) argues that arguments that paint a picture in which identity is a choice and hybridity a product of a new transnational age often disregard the uneven and unequal access to power and resources among individuals in society and in global capitalism. In doing so, they fall into the same trap as the essentialist approaches that they rightly criticise (2001, p. 637). In this paper I argue that while all identities are fluid and hybrid, the space in which their fluidity and hybridity is expressed and lived is not a level playing field, but is one that is constrained by unequal access to economic, social and political power. Using this theoretical approach allows analysis of how structures such as class, ethnicity, gender and age intersect in women's lives with discourses of religion, race, assimilation and sexism and play an important role in the construction of hybrid identities. 


\section{Islamophobia and Racism}

In this paper I argue that Islamophobia is a form of contemporary racism which impacts on women's experiences of activism. However the meaning of the term 'Islamophobia' and the nature of its relationship to racism are contested. Miles (2003) argues that Islamophobia intersects with racism by defining Muslims as a racialised group as well as a religious 'Other' and Islam as homogenous, essentially different from the West and inferior (Miles, 2003, p. 165). Halliday (1999) criticises those who use the term 'Islamophobia' as putting forward the idea of a pure and authentic Islam which is under attack. However, Miles defends the use of the term arguing that the non-existence of a pure and authentic Islam does not nullify the presence of Islamophobia just as the non-existence of race as a phenomenon does not nullify the existence of racism (2003, p. 165). In fact Halliday has confused Islam with Islamophobia, an ideology which involves the essentialising and homogenising of people of diverse ethnic, linguistic and cultural backgrounds. In the Australian context, racism against Muslims is certainly not a new phenomenon and racialised coverage of Arabs and Muslims has been present in the Australian media since the 1980s (Manning, 2006, pp. 22-23). Poynting et al. (2004) argue that homogenising, essentialising discourses which blur the lines between ethnicity, religion and culture serve a specific purpose in contemporary Australian society which intersects with racism. They argue that discourses around Arabs and Muslims in Australia are not simply racialised, i.e. reduced to a set of essentialised 'racial' characteristics, but racialised in order to construct them as the 'Other' and as less human and evil (2004, p. 45). In this paper I argue that Islamophobia and racism towards Muslims are more than a series of lies or myths which can be blown away to reveal the truth (Said, 1995, p. 6). The ideology of Islamophobia reveals the very real and concrete powerrelationships that persist in contemporary Western states, including Australia. These are 'security states', in that they are states in which the domestic population is subjected to unprecedented surveillance, search and detention powers by the police and security organisations in the name of 'national security'. Islamophobia is therefore intimately connected with the political and economic interests of contemporary states, in which any form of activism, dissent and difference, be it ethnic, religious or sexual difference, is equated with terror and a threat to national security (Young, 2003, p. 8). 


\section{Gender and the Politics of Assimilation}

Ideas of 'civilising the Orient' which were used as a pretext for colonial rule in the $19^{\text {th }}$ and $20^{\text {th }}$ centuries were gendered in that they posited that Arabs and Muslims were both unable to govern their own countries and unwilling to protect 'their' women. (Young, 2003; Bahramitash, 2005; Rostami-Povey, 2007). In the post-Cold War era the idea of non-Westerners and particularly women as passive victims in need of rescue has gained further impetus through the rise of humanitarian and human rights discourses. Laleh Khalili argues that human rights discourses transformed the politics of resistance; revolution and liberation, which were products of the mass movements of the 1960s and 1970s, into a humanitarian project of securing aid for the countless, nameless and objectified victims of hunger, war and conflict worldwide. This shift, which occurred in the context of the US's rise in status to the world's only remaining superpower, has she states, de-politicised issues of war, conflict and hunger and in turn produced a "politics of pity", which denies the possibility of agency and the capacity and necessity of resistance (Khalili, 2007, p. 36). In more recent years discourses in which Muslim and Arab women are presented as passive and oppressed have interconnected with 'Feminist Orientalism' an ideology which Parvin Paydar argues uses the language of women's liberation to justify military action in Arab and Muslim majority countries (Paydar, 1995). This situation has been worsened by the failure of Western feminism to take up issues of war and racism. Stanley and Wise argue that the lack of a women's movement in Western countries combined with the institutionalisation of academic feminism, has allowed women's liberation to be used in a way that has at best, failed to oppose war and racism and at worst, colluded with the neo-conservatives and supported assimilationist policies (Stanley and Wise, 2000). Sherene Razack (2008) argues when gender is relied on to support the politics of assimilation, a choice is presented to Muslim women: "either we take the cure (the bombs on our heads and the camps), or we endure patriarchal violence” (2008, p. 18). The 'choice' that is set up here between oppression and assimilation is problematic as it assumes that Western women are liberated. Secondly arguments which fail to criticise the essentialist 'cultural-religious' framework through which debates around Arab and Muslim women are conducted and present assimilation as a 'choice' end up supporting essentialist notions of culture and white racial superiority (Fekete, 2008, p. 10). 


\section{International Comparative Frameworks}

In recent years a number of studies have been conducted which utilise international comparative frameworks in an effort to go beyond essentialising discourses and focus on the material conditions of women's lives (Rostami-Povey 2007; Sadig Al Ali 2007). In Afghan Women (2007) Elaheh Rostami-Povey argues that Afghan women living in Iran and Pakistan have resisted both the Taliban and the US invading forces by organising within their communities and establishing schools, healthcare facilities, orphanages and NGOs. For example, In Iran, Afghan women have set up Madarese Khodgaran (self-run schools) with an emphasis on those focussing on the education of girls (2007: 86). Rostami-Povey argues that Afghan women through their own efforts have created a space in which they are active agents in organising and leading their own communities. This struggle for community survival in diaspora has extended to the struggle for women's rights and has had an effect on how they and their communities perceive gender relations and gender equality (2007, p.107).

Although it does not specifically refer to activism, this important analysis provides a very different picture to prevailing views of women in Muslim majority countries as passive victims of male oppression and allows us to question the common idea that political activism and resistance to patriarchy is easier for women in Western 'liberal democratic’ countries such as Australia. More research needs to be conducted in order to develop fully a comparative framework which discusses activism in Iran and in Australia. However, my initial research, based on interviews with Iranian activists carried out in December-January 2008-2009 and Australian activists in 2008, supports Rostami-Povey’s findings. Women activists living in Muslim majority countries such as Iran have faced numerous difficulties as activists, yet they have been able to construct their own 'emancipatory frameworks' based on their interaction with the changing meaning of their faith, their cultures, their national, community and personal histories and their struggle for gender equality. In Iran the creation of this space has been strengthened by the fact that women in Iran have more rights than in neighbouring US backed states. They have a strong presence in the workforce, in politics, are highly educated and make up 65\% of all students entering university (Bahramitash, 2005; Rostami-Povey, 2007). Contrary to popular views of the country, the United Nations Development Programme’s 'Human Development Report' for 2007/8 ranks Iran as slightly above the USA in terms of overall gender 
equality. ${ }^{1}$ There is also a large and active women's movement in Iran which has articulated critiques of patriarchal readings of Islamic religious texts, campaigned against discriminatory laws and won significant victories (Mir-Hosseini and Tapper, 2006). In an interview conducted in Tehran in 2008, Iranian NGO leader Nahid Ashrafi described the successful campaign of the women's movement against laws that restrict the passing on of citizenship by mothers to their children:

We were able to argue in the Sixth parliament that Iranian women who married Afghan men (or any other foreign men) should be able to pass on their citizenship rights and nationality rights to their children. This was a great step forward. ${ }^{2}$

The active and visible participation of women in politics has a long history in Iran, from resistance to European colonialism in the $19^{\text {th }}$ century to the mass participation of Iranian women in the revolution of 1979. This historical experience has enabled women to challenge restrictive gender relations within their own communities from within the framework of an Islamic culture. However, the experience of Arab and Muslim women in the West is more complex. In Australia and in Western countries, hostility towards Islam and the prevalence of Islamophobic discourses means that it is much more difficult for Arab and Muslim women to use Islamic frameworks to argue for their rights. They are constantly having to defend their cultures and their communities, not just from racist ideas but from an ideology that justifies support for military action in Muslim majority countries and maintenance of the contemporary security states.

\section{Activism in Australia}

In August 2008 I spoke with three women activists based in Sydney. They were from diverse backgrounds in terms of class, age and ethnicity, had differing political affiliations and were involved in different campaigns. Sabrine Elkhodr is an activist

\footnotetext{
${ }^{1}$ UNDP Human Development Report 2007/8 lists GDI (Gender Disparity Index) as a percentage of HDI (Human Development Index). The lower the GDI as a percentage of HDI, the greater the indicators of gender inequality. Iran's GDI as percentage of HDI is $98.8 \%$ while the USA is listed at 98.5\%. The UNDP ranks Iran 95th in its list of nations in terms of gender equality and the US as 107th. http://hdrstats.undp.org, accessed 13/04/08.

${ }^{2}$ Interview with Nahid Ashrafi in Tehran, Wednesday 31 January 2008, Nahid Ashrafi is the director of Hami NGO (in support of Afghan women and children refugees in Iran). She has recently set up a school of Afghan children in Khayrabad near Tehran called Kamal School.
} 
who works with global anti-poverty campaigns and has been involved in anti-war and anti-racist campaigns. Sevgi Yildiz is a community welfare activist currently working with the Feza Foundation in Sydney with young migrants from Turkey and other Islamic countries and communities. Councillor Malikeh Michaels is a Greens activist and Councillor in Auburn. Despite their differences, a number of common themes emerged from my conversations with these activists. They rejected the notion that they are passive victims of male domination or that their marginalisation in diaspora is due to 'cultural' factors outside of the political arena. Sabrine Elkhodr argues that very real problems facing Muslim communities in Australia have been neglected in favour of a type of public discourse that consists of essentialist pronouncements on issues such women's oppression and the hijab:

...people tend to focus so much on what's going on overseas or for example, such and such a person has been talking about polygamy, lets bash them up, or this person's talking about the hijab. We focus so much on those types of issues, and there is so much public discourse on those issues that, the issue of community welfare is neglected.

She argued that what was important in terms of 'community welfare' was access to health, education and employment. Problems in the community she argued were perceived to be a result of inherent problems within Muslim or Arab culture were actually a result of social and economic marginalisation:

I read a statistic that there is probably a higher unemployment rate within certain Islamic communities in Sydney than there is in the rest of Australia, you have to ask yourself why is that? Why is that happening? It's certainly not something which is inherent within that culture.

However, Sabrine argued that Muslim and Arab women were not simply passively accepting marginalisation but were fighting to oppose racism and to strengthen their communities. This contradicts common perceptions of the Muslim community in Australia as being homogenous, conservative and insular: 
I hate to sound clichéd but the media have drummed it in to the Australian community over the last few years that the Muslim community is very isolated and very insular and anyone who happens to have a Muslim name or wear a scarf, its assumed that they can't speak English, they're not educated, they don't know what they're talking about. You do want you want and leave us be, its that kind of an attitude, and then when they realize that you actually are educated, that you want to engage with them, they're surprised.

Sabrine stated that cross-cultural collaboration in movements was essential to their success particularly in challenging racism and war and in fighting for community welfare:

If you are living as a community, you can't be split up into groups of us and them or you and me, if you are working for a cause and you're working for society, you have to work as a cohesive whole otherwise anything that you do is going to disintegrate or be attacked by someone else and that would be pointless, at the end of the day.

The three participants argued that through their activism they are creating identities that challenge ideas of Australian white Christian exclusivity which they felt constitutes Islam as the threatening 'Other' and uses this construction to justify war and social exclusion. In opposing this, they felt that they were not rejecting notions of Australian-ness or acting as the 'long distance nationalists' that Brubaker (2005: 2) describes but articulating positive ideas of Australian-ness based on their political identifications, experiences and engagement in society. Sevgi Yildiz describes her work with a Turkish community welfare foundation as helping young migrants from Turkey and other Islamic communities and countries discover and create an Australian-Turkish-Muslim identity:

What we do is basically teach children how to become better social beings, help them with their studies and at the same time teach them social morals, Australian morals. Because they're mainly Turkish students, they're brought up by their parents who are from Turkey. So we help them understand what Australian-ness is. How they don't have to be what their parents want them to be all the time, they can create their own identity as an Australian Muslim, as a Turkish Muslim. 
Councillor Malikeh Michaels is a Greens Councillor for Auburn who describes herself as an 'Anglo convert'. She describes how she has forged an Australian Muslim identity that challenges views of Muslims as un-Australian:

...what I do by wearing a scarf and presenting myself as a Muslim, is saying, hey I'm an Aussie, I'm from Queensland, from north of Brisbane, you couldn't get anymore Aussie than me, and I can sit down and have a yarn on any topic and speak in all the slang and lingo, of country Australia. No one can take that away from me, no one can deny that, no one can say you're not really an Australian and it doesn't matter then what religion I practice.

In constructing identities that reflected their experience, these activists stressed that they were not accepting assimilation which they saw as problematic and racist. Sabrine distinguished between the ideas of 'living 'peacefully' and assimilation:

You can't just kind of sweep it under the rug and say, if they don't like it here, chuck them overseas, because members of the Muslim community have chosen to come here, they want to live here, they want to live here peacefully, but that doesn't mean that you ignore the fact that we also have specific needs that we'd like met, that doesn't mean that we're against Australian society or against Australian values.

However, the participants argued that this work is made much harder by Islamophobia and the resurgence of the politics of assimilation in Australia. Activism, by its very nature involves acts of imagining and advocating difference as activists articulate ideas and strategies for social transformation. Sevgi argued that in a society where even imagining difference has not been tolerated, at least by the political mainstream, the creation of identity becomes an increasingly difficult task as the rejection of assimilation becomes equated with a rejection of Australian-ness:

In Australia we've had the white Australia policy and then assimilation and then multi-cultural Australia, that was our culture for a while, but now the attack is on, whatever is different is not welcome because it's perceived as a threat. 
She described how the forging of Australian-Muslim identities is hard for the young Muslim migrants she works with not because of anything that is inherent in their culture but due to the hostility they feel directed to them by mainstream views of Australia as exclusively white and Christian:

Even though they are 18, they can get stuck in the idea that I have to keep hold of my culture. They are holding on to it so tightly because they feel that everyone is attacking them. What happens is that they can't make friends and all that sort of stuff because everything is so weird to them. They don't want to embrace or they can't embrace Australia and they don't feel that they will be welcome either. They have issues finding jobs, when I say why don't you go for a job here and there they say, no they wouldn't want me, because I'm not this or that or I don't look a certain way, I say you'll be fine, just go, but they feel that they're never going to be able to mold into Australia.

The politics of assimilation, Malikeh argued, was a major characteristic of the Howard years and has had a lasting impact on activism in Australia:

The Howard Era was the era of fearing anybody different and very much the 'us and them' attitude..." “When I think about Islamic activists, I think people are scared, because of the last ten years of hysteria and xenophobia so I think people are very fearful of being seen as activists because they might be seen as being stirrers or troublemakers, as un-Australian.”

Malikeh criticised perspectives that fail to recognise that Arab and Muslim women's expressions of faith are complex and multi-layered. The wearing of hijab, for example can have a number of different meanings which can include expressions of opposition to war and cultural imperialism. Like a number of Muslim women, Malikeh describes choosing to wear the hijab after September 11 2001, as an expression of her faith and also partly as a political act, a way of identifying with the 'Other' and of expressing her opposition to the attacks on Muslim countries:

September 112001 brought up a resurgence of Islamic identity, which I became a part of because I'm a Muslim, I'm not a bad person and I'm going to show the world 
that I'm proud to be a Muslim." "So, I put the scarf on and that was a major act of activism.

\section{Conclusion}

A comparative analysis of women's resistance has the strength of being able to focus on the political context in which that resistance occurs. In this paper I have argued that women in Muslim majority countries have been able to use Islamic frameworks as vehicles through which they have successfully argued for their civil and gender rights. Contrary to views that assume that activism is easier for women in Western 'liberal democratic' countries such as Australia, I argue that it has been easier for women in Iran to construct frameworks and identities through which they resist patriarchy, war and neo-liberalism. Arab Muslim women living in Western countries and Australia are also resisting ethnic stereotypes, challenging war and neo-liberal attacks on their communities. They have resisted the construction of their identities by the dominant culture and have put forward a view of Australian-ness that is based on their participation in society and their experiences of how class, gender and ethnicity intersect in their lives. However, their task is being made much harder by the level of racism and hostility directed at Arab and Muslim communities.

Women's activism needs to be contextualised, i.e. seen within the context of the actual material conditions in which women live. Responses to these material conditions and to oppression need to be recognised in their complexity. If we want to change the way in which women respond to the material conditions in which they find themselves, I argue that we should focus, as activists on changing the material conditions themselves rather than seeking to change women's responses after the fact. Arguments that focus purely on the symbolic meaning of women's responses without addressing the political context in which these responses occur run the risk of falling in to the trap of accepting assimilationist discourses that are based on notions of passivity, clash of cultures and cultural exclusivity. Therefore, 'After the Neo-Con men', building broad movements that oppose war, racism and Islamophobia remains essential for activists and is part of an international movement which can connect into and strengthen the struggles of Arab and Muslim women. 


\section{Acknowledgements}

I would like to thank Sabrine Elkhodr, Christina Ho, Malikeh Michaels, Sevgi Yildiz and the anonymous reviewers for their advice, knowledge and ideas, all of which greatly contributed to this paper.

\section{References}

Anthias, F. 2001, 'New hybridities, old concepts: the limits of “culture”', Ethnic and Racial Studies, vol.24 no.4, pp. 619-641.

Anthias, F. \& Yuval-Davis, N. 1992, Racialized Boundaries Routledge, London.

Bahramitash, R. 2005, 'The War on Terror, Feminist Orientalism and Oriental Feminism: Case Studies of Two North American Bestsellers’ Critique: Critical Middle Eastern Studies, vol. 14 no. 2 pp. 223-237.

Brubaker, R. 2005, 'The ‘diaspora’ diaspora', Ethnic and Racial Studies, vol. 28 no.1, pp. 1-19.

Cook, B. \& Kothari, U. 2001, Participation: The New Tyranny? Zed Books, London.

Fekete, L. 2008, Integration, Islamophobia and Civil Rights in Europe, Institute of Race Relations, London.

Gilroy, P. 1993, The Black Atlantic, Harvard University Press, Cambridge, Mass..

Halliday, F. 1999, '”Islamophobia” reconsidered' Ethnic and Racial Studies, vol. 22, no. 5, pp. 892-902.

Khalili, L. 2007, Heroes and Martyrs of Palestine, The Politics of National Commemoration, Cambridge University Press, Cambridge.

Laws, S., Harper, C. and Marcus, R. 2003, Research for Development, A Practical Guide, Sage, London.

Manning, P. 2006, Us and Them, A Journalist's Investigation of Media, Muslims and the Middle East, Random House, Sydney.

Miles, R. 2003, Racism, Routledge, London.

Mir-Hosseini, Z. \& Tapper, R. 2006, Islam and Democracy in Iran: Eshkevari and the Quest for. Reform, I. B. Tauris, London.

Paydar, P. 1995, Women in the Political Process in Twentieth Century Iran, Cambridge University Press, Cambridge.

Poya, M. 1999, Women, Work and Islamism, Ideology and Resistance in Iran, Zed Books, London.

Poynting, S., Noble, G., Tabar, P., Collins, J. 2004, Bin Laden in the Suburbs, Criminalising the Arab Other Sydney Institute of Criminology, Sydney.

Razack, S. 2008, Casting Out, The Eviction of Muslims from Western Law and Politics, University of Toronto Press, Toronto.

Rostami-Povey, E. 2007, Afghan Women: Identity and Invasion, Zed Books, London. Sadig Al-Ali, N. 2007, Iraqi Women, Untold Stories from 1948 to the Present, Zed Books, London.

Said, E. 1996, Representations of the Intellectual, Vintage, New York.

Said, E. 1995, Orientalism Penguin, London. 
Stanley, L. and Wise, S. 2000, 'But the Empress has no Clothes! Some Awkward Questions about the 'Missing Revolution' in Feminist Theory', Feminist Theory, vol. 1, pp. 261-88.

Young, I. M. 2003, 'The Logic of Masculinist Protection: Reflections on the Current Security State', Signs: Journal of Women in Culture and Society, vol.29 no.11, pp. 1-25. 